\title{
Kushite Stamp Impressions from Selib 2, Sudan
}

\author{
RoKSANA HAJDUGA
}

\begin{abstract}
More than two hundred sealings have been found since 2010 at Selib 2, a small Meroitic settlement in the Dongola Reach. This group come from the same context, in the S2/1/2010 storehouse and the most prominent building within the settlement. This paper focuses on selected impressions of thirty-one seals found on sealings and discusses them mainly in terms of iconography. Motifs from the sealings are both figural and non-figural. They reflect Meroitic beliefs, culture and politics. The catalogue and description of individual sealings, complete with photographs and drawings of stamp impressions, provide a firm base for preliminary observation regarding religion, symbols used by administrations and political propaganda, as well as allowing one to trace external influences and adaptation of foreign patterns.
\end{abstract}

Keywords: Nubia, Kush, Meroitic period, Selib 2, stamp seal, sealing, trade, transport

Roksana Hajduga, Institute of Mediterranean and Oriental Cultures, Polish Academy of Sciences, Warsaw; rhajduga@iksio.pan.pl; (D) 0000-0002-7220-2571

The Dongola Reach region stretches between the Third and Fourth Nile Cataracts in Upper Nubia, extending approximately $150 \mathrm{~km}$ downriver of the Fourth Cataract (Fig. 1). During the Southern Dongola Reach Survey 1997/1998, ${ }^{1}$ three sites were discovered in this region on the west bank of the Nile, near the modern village of Selib: Selib 1 with the church dated from the six-century AD, Selib 2 - a Meroitic settlement dated to the first/secondcentury BC, and Selib 3 - an Early Christian house.

Archaeological works in 2010 and 2011 focused on the store building S2/1/2010 at Selib 2 (Fig. 2). It covers $c .900 \mathrm{~m}^{2}$, was constructed of mud-bricks and preserved mainly at the foundation level. The entrance was located in the east. Rooms contained storage vessels dug into the ground or free-standing, beer jars of various types and ceramic material complemented by numerous kitchen utensils and amphorae fragments. ${ }^{2}$

\footnotetext{
Żurawski 2000.

2 Żurawski et al. 2014: 338.
} 


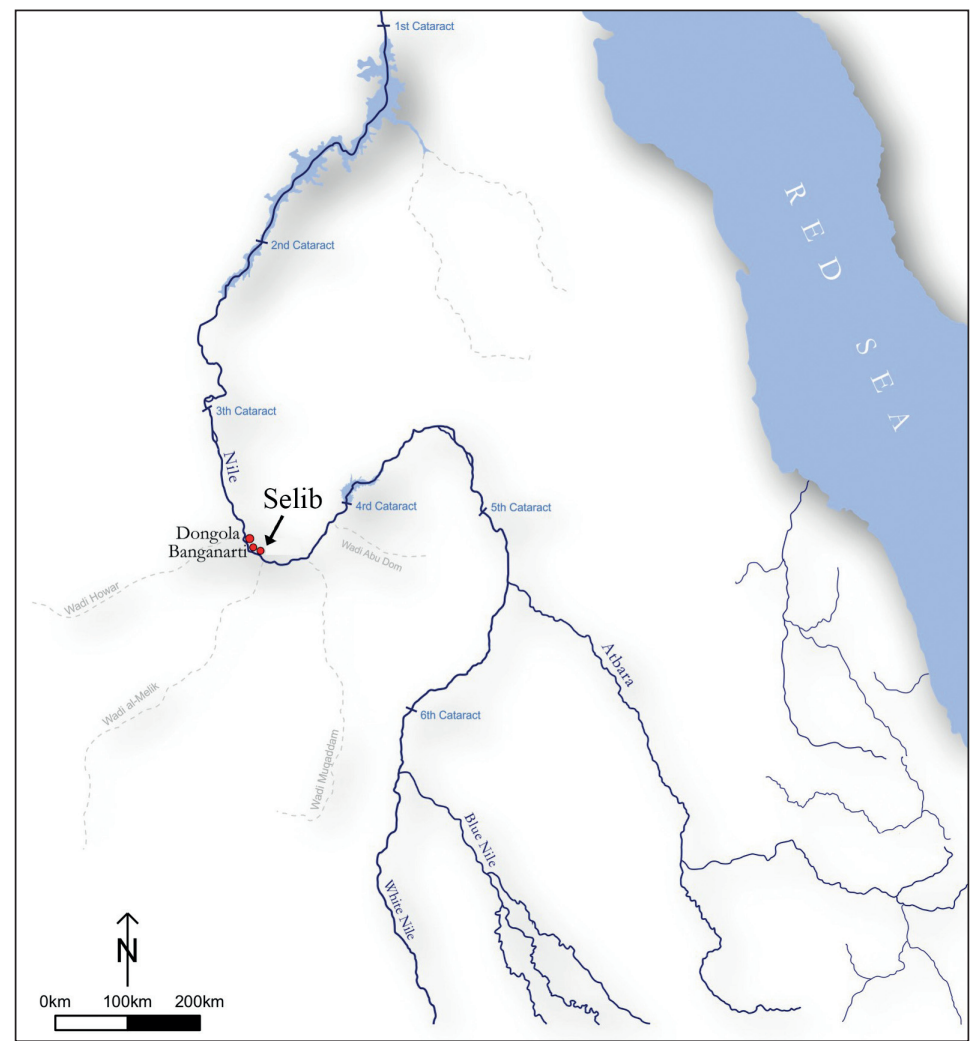

1. Location of Selib 2 within Dongola Reach region (Drawing: A. Cedro).

Further to the west was another complex (S2/1/2011), undoubtedly used simultaneously with the S2/1/2010 warehouse. There is no roofing remains, but the preserved floor at the entrance may indicate that this area was covered. The open courtyard in the central part of the complex was a convenient reloading/loading or possibly a trade space. In the southern part of the complex there were five storage rooms. ${ }^{3}$ In the later phase or during reconstruction works, another room complex (S2/2/2011) was added to the southern corner of $\mathrm{S} 2 / 1 / 2010$. Based on the spatial organisation of the $\mathrm{S} 2 / 2 / 2011$ structure and its inventory, we assume it was most likely a residential house. ${ }^{4}$

Numerous storage vessels and mud sealings indicate the storage function of rectangular rooms creating S2/1/2010. At the same time, large quantities of ground stone tools associated with grinding, such as querns and pounders, suggest that some production activity took place in this area as well.

\footnotetext{
3 Żurawski et al. 2013: 287-294.

${ }^{4}$ Żurawski et al. 2014: 337, Fig. 10; S2/2/2011 is marked as rooms 5-10 and room 22 on the plan from 2011.
} 


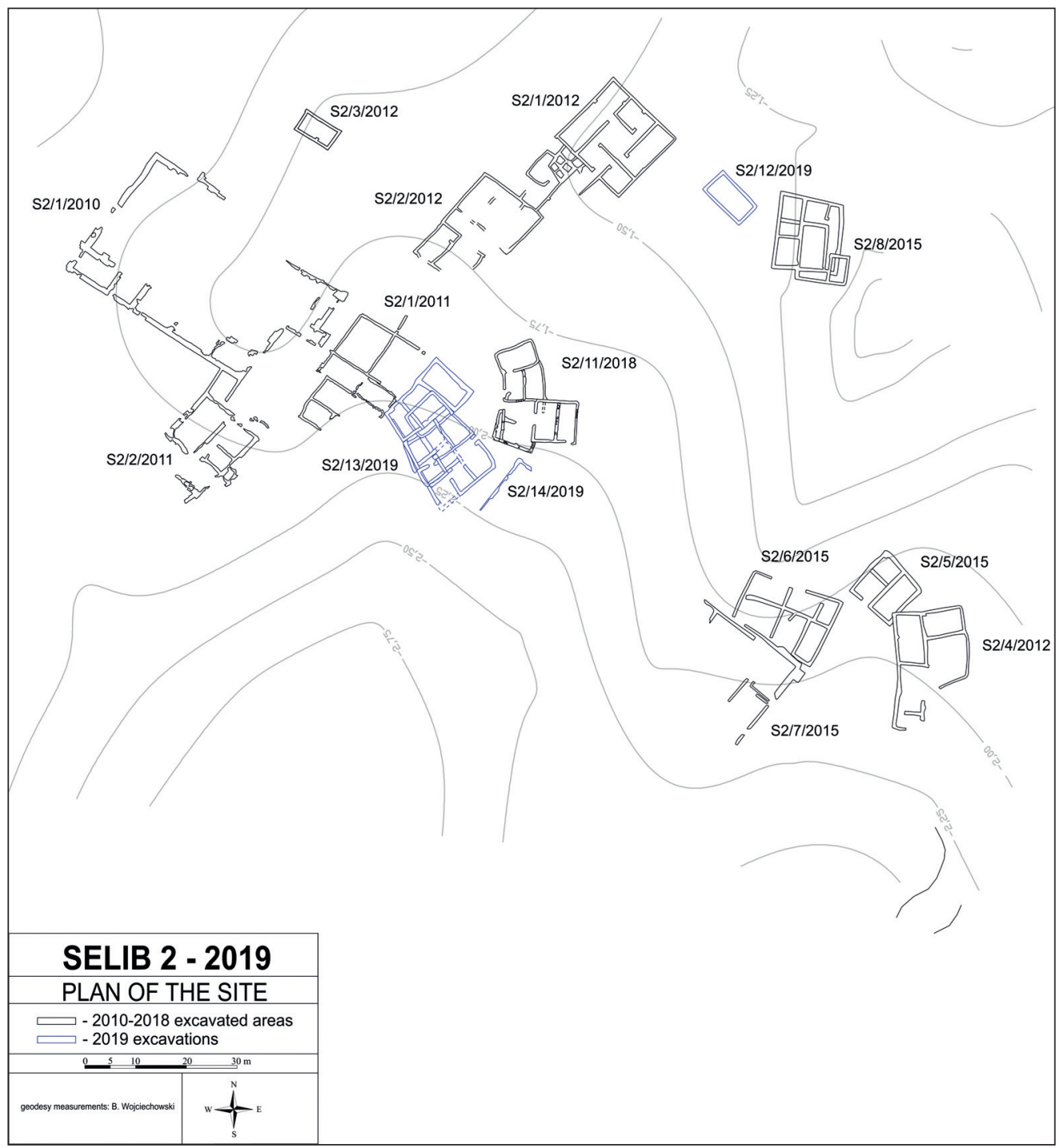

2. Selib 2, plan of the site after 2019 season (Drawing: R. Hajduga).

The precise extent of the Meroitic settlement at Selib 2 is hard to establish, but ongoing geophysical work allows us to reconstruct the gaps in the urban plan of the site. The most prominent structure unearthed in the course of excavations conducted at the site up to 2019 is the discussed rectangular store building S2/1/2010, surrounded by warehouse units and residential houses to the east and south. ${ }^{5}$

${ }^{5}$ Hajduga, Momot, Łopaciuk 2021. 


\section{CLAY SEALINGS}

Clay sealings were found during each field season, but in 2011 a concentration of over two hundred fragments was discovered in a single context inside room 1 of S2/1/2010. Most of them were recorded in the filling of the room, but some also in the mortar between the bricks of the walls. They were made of grey Nile alluvial clay with varying mineral and organic inclusions.

The broken sealings must have been systematically removed from storehouse S2/1/2010 and disposed of since they have not accumulated large quantities. A careful study of the negatives of sealed objects is still not finished. However, one might assume that these sealings had initially been placed on storage jars and amphorae, which were found in the same context as sealings. Sealings were stamped with oval or circular stamp seals, though stamp impressions are often illegible since sealings are mostly fragmentarily preserved.

\section{CATALOGUE OF CLAY SEALINGS}

The catalogue includes impressions of selected thirty-one seals attested on sealings from Selib 2. It presents measurements, photographs, drawings (Figs 3-16), and descriptions of the images and quotes seals and seal impressions with similar representations as well as other iconographic parallels.

cat. no. 1

shape: circular; dimensions: d. $3 \mathrm{~cm}$ (preserved fragmentarily).

Description: king kneeling on one knee and holding a sceptre in his right hand. He wears the white crown of Upper Egypt - the hedjet, a short dress, and holds a was-sceptre. In front of him is an ankh sign and a lotus flower bud, the stem of which follows the curve of the field in its right part. This image is probably repeated twice on this sealing, although the second impression is largely obliterated.

Commentary: This stamp impression is similar to a sealing from Jebel Barkal (JB24), where two figures face each other, and the one on the left is wearing a short dress and hedjet crown with streamers. ${ }^{6}$ Amun holding a similar was-sceptre appears on the signet-ring stamps from Meroe. Three seals from this site show a sitting or standing Amun holding a sceptre in one hand and an ankh symbol in the other. ${ }^{7}$ The same design is visible on the scarab seal from Semna, which shows a walking figure in a short dress and holding a was-sceptre. ${ }^{8}$

cat. no. 2

shape: circular; dimensions: d. $2.9 \mathrm{~cm}$.

Description: a kneeling figure with a crown on his head. It has a zoomorphic face that is not recognisable, but it seems likely to be a ram's head. The figure kneels on one knee and

\footnotetext{
6 Vincentelli 1992: 117.

7 Priese 1992: 30, Figs 28a, 28c; 34, Fig. 31a.

8 Reisner 1914: P1. V, Fig. 10.
} 

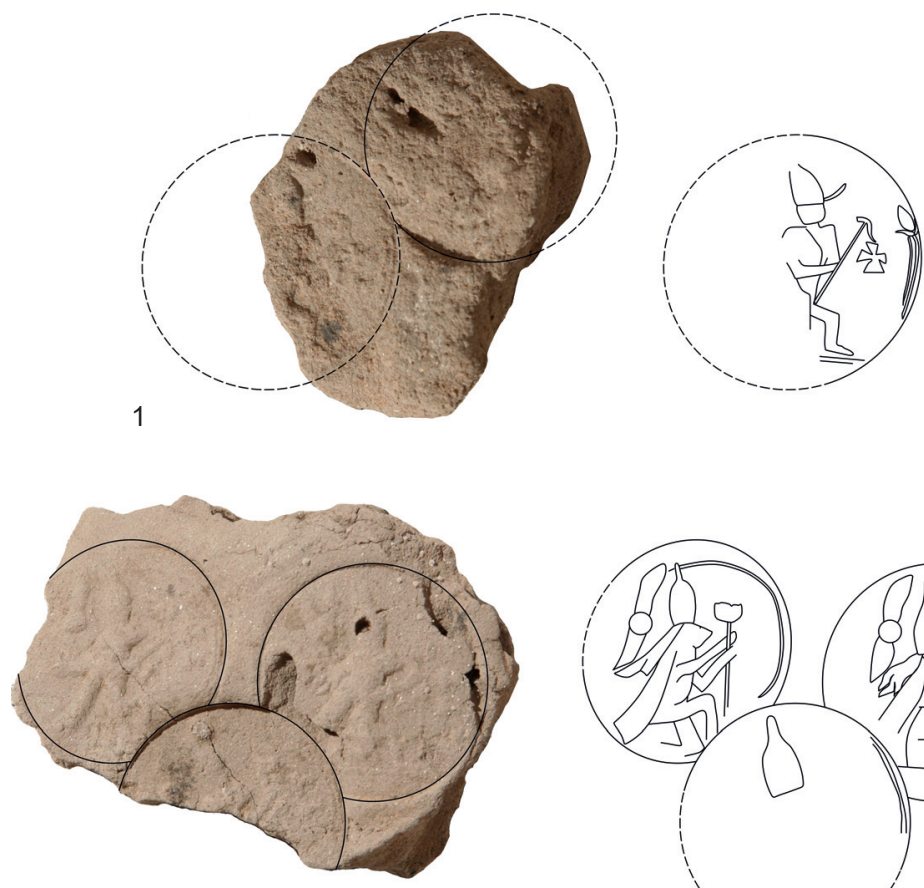

2

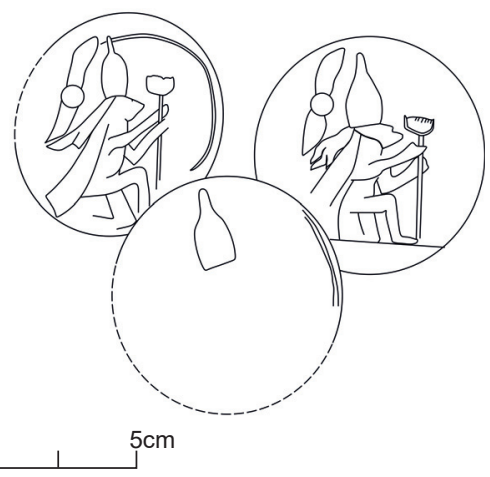

3. Sealings with stamp impressions (cat. nos 1-2) from Selib 2, S2/1/2010 (Phot. K. Molga; drawing: R. Hajduga).

holds a sceptre in front of him with both hands. The crown resembles a double crown with streamers on the back. A cape flutters behind the figure, which wears a short robe. Behind him is a winged sun disk. This seal impression is attested three times on this sealing. Commentary: A ram-god Amun of Napata is often depicted with a solar disk on his head, one of the attributes of this deity. However, the similar winged sun disk is also known from clay sealings from Jebel Barkal (JB10, JB11), where god Apedemak is depicted as a lion. ${ }^{9}$ A sun disk emphasises his connection to the solar cult. ${ }^{10}$ The cat. no. 2 also resembles the votive plaque of King Tanyidamani from the Temple of Apedemak in Meroe. ${ }^{11}$ A ram-headed Apedemak is also depicted on the wall of M620, the Amun temple in Meroe and the Central Temple in the Great Enclosure of Musawwarat es Sufra. ${ }^{12}$

\footnotetext{
9 Vincentelli 1992: 112.

10 Žabkar 1975: 13-36.

11 Wenig 1978: 204.

12 Wenig 1978: 67-68.
} 
cat. no.: 3

shape: circular; dimensions: d. $2.3 \mathrm{~cm}$ (preserved fragmentarily).

Description: archer facing to the right. The image is not complete, but the feet indicate the figure's orientation. He holds a long bow in front in one hand and wears a short robe with an unidentified object attached to his waist. In front of him is an elongated winged solar disk.

Commentary: The figure from the impression could be compared with Apedemak shown as a man with a lion's head or as a lion, often with a bow and an arrow, symbols of the god of war. He also wears a hemhem crown, a determinant of his power and a sun disk characteristic for the solar cult. Although the crown is not preserved on cat no. 3 and the details are indistinct because the sealing is damaged, the discussed seal impression appears to depict many attributes of Apedemak. It might have been similar to a seal impression JB20 from Jebel Barkal. ${ }^{13}$

cat. no. 4

shape: oval; dimensions: 2.6 × $2.3 \mathrm{~cm}$ (preserved fragmentarily).

Description: a figure facing left, holding a spear or an arrow above his head and pointing by it towards the wild game. In the other hand holds two small oval-shaped objects. It seems that it may be a ram-headed figure due to the schematically marked horn on the side of his head, but this part of the impression is unclear, and the identification is still debatable. The left part of the scene is illegible. On the same sealing, on the right and left, the traces of the other seal impressions are visible, but none is preserved to the extent that would allow one to state if they were made by the same seal.

Commentary: Two small oval-shaped objects held by the figure are hard to interpret. A similar representation appears on the gold signet-ring from Meroe, where a winged figure with a solar disk and uraeus held a spear and two small oval-shaped objects (rattles?) in front of himself. ${ }^{14}$

cat. no. 5

shape: oval; dimensions: h. $2.8 \mathrm{~cm}$ (preserved fragmentarily).

Description: a figure in a crouching position, facing left and holding a staff or a sceptre in front of him. He is wearing a short robe and a sandal.

cat. no. 6

shape: circular; dimensions: h. $1.8 \mathrm{~cm}$ (preserved fragmentarily).

Description: a head of an unidentified figure. The size of the stamp field suggests that only the head could fit it. The visible shape is not distinctive, so it can also be a solar disk with two uraei on the sides.

\footnotetext{
13 Vincentelli 1992: 109.

14 Priese 1992: 38, Fig. 36b.
} 


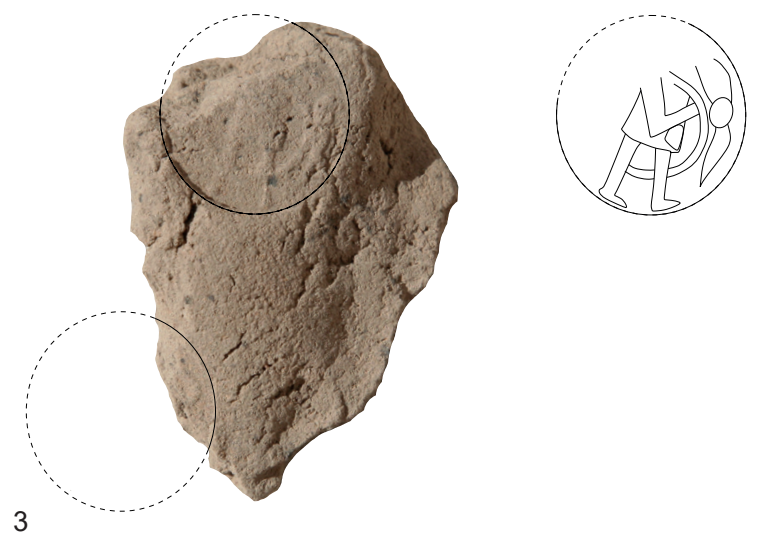

4
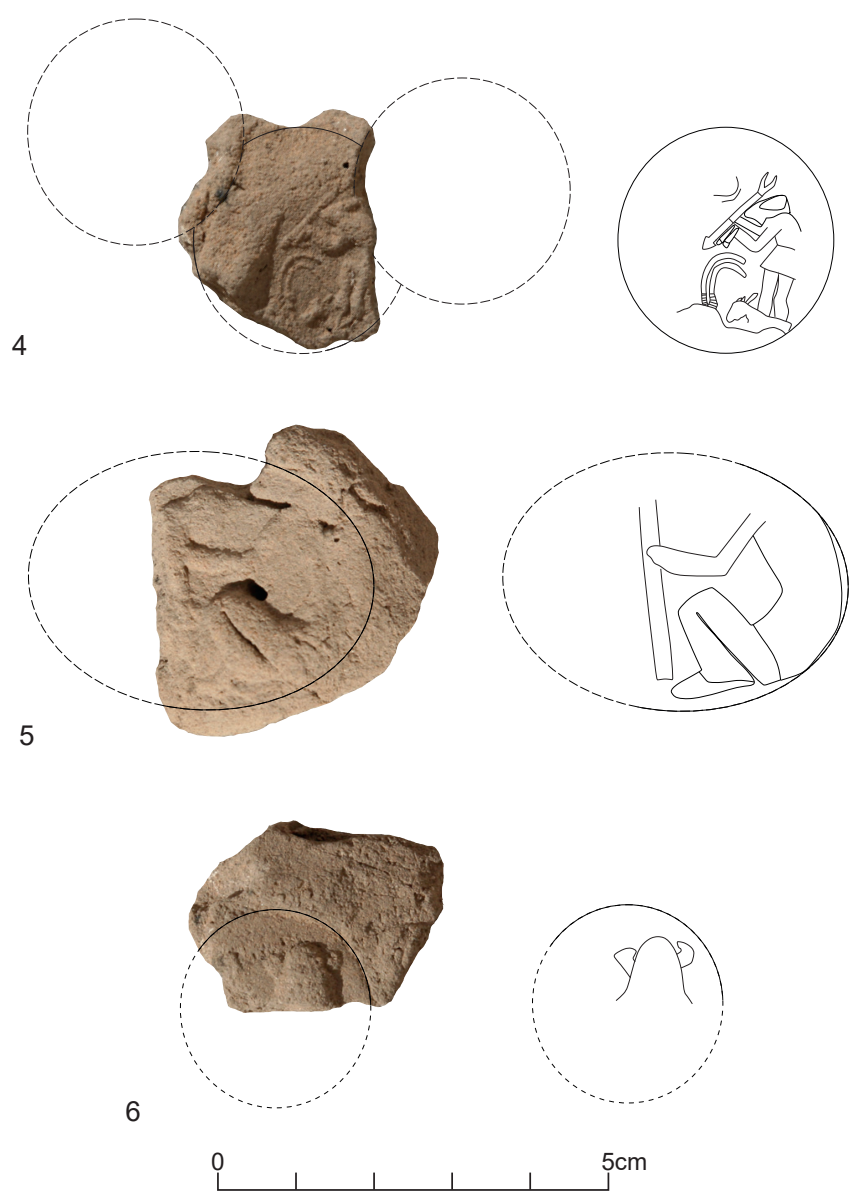

4. Sealings with stamp impressions (cat. nos 3-6) from Selib 2, S2/1/2010 (Phot. K. Molga; drawing: R. Hajduga). 
cat. no. 7

shape: oval; dimensions: 2.2 x $1.4 \mathrm{~cm}$ (preserved fragmentarily).

Description: elongated white crown, similar to cat. no. 6, but more elaborated. An uraeus extends on the right side and a coronet is on a crown base. To the left is a sun disk with two uraei on its sides. The figure wearing the crown is not preserved, but we can distinguish a wing with marked feathers on the left side.

Commentary: It seems the figure was depicted en face. One might speculate that the upper part of the head has been similar to images of a lion, e.g. JB14 or JB8, depicted with round ears. ${ }^{15}$ A similar sun disk with two uraei on the sides is visible on the signet-ring stamp seal from Meroe. There, the sun disk is located above the head of Amun sitting on the throne. ${ }^{16}$ However, in the case of cat. no. 7, nothing indicates such reconstruction.

cat. no. 8

shape: oval; dimensions: $3.3 \times 2.4 \mathrm{~cm}$.

Description: a kneeling figure facing right, wearing a short robe. He is kneeling on one knee, with the other leg bent at the knee and arms bent at chest level. In each hand, he holds unidentified elongated object. The upper part is significantly eroded and prevents complete reconstruction of the image.

cat. no. 9

shape: circular; dimensions: h. $2.3 \mathrm{~cm}$ (preserved fragmentarily).

Description: a figure facing right, walking on an arched base. The head and left arm are not preserved. The right arm is bent at the abdomen level while a long wing projects from his back. It can be assumed that a similar wing was depicted on the opposite side, which is visible on the second impression from the same sealing. The man has broad shoulders, widely spaced legs. In front of him is a bird (perhaps falcon), above which two elongated objects are visible, probably held by the figure.

cat. no. 10

shape: circular; dimensions: d. $2.2 \mathrm{~cm}$ (preserved fragmentarily).

Description: a walking figure facing right. The upper part of the body is not preserved. The figure walks on wide-set legs, with a bent right arm and a stick or sceptre in its left hand. In the left part of the field, the outline of a wing is visible. A complete wing is preserved on the second impression of the same seal. Behind the figure is an unidentified curved object.

Commentary: similar to cat. no. 9.

\footnotetext{
15 Vincentelli 1992: 109.

16 Priese 1992: 34, Fig. 31a.
} 

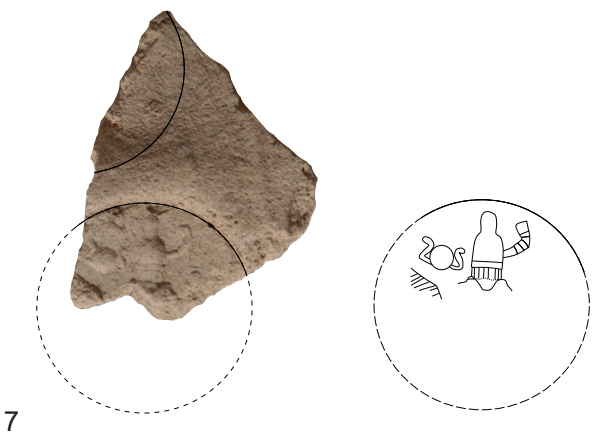

8
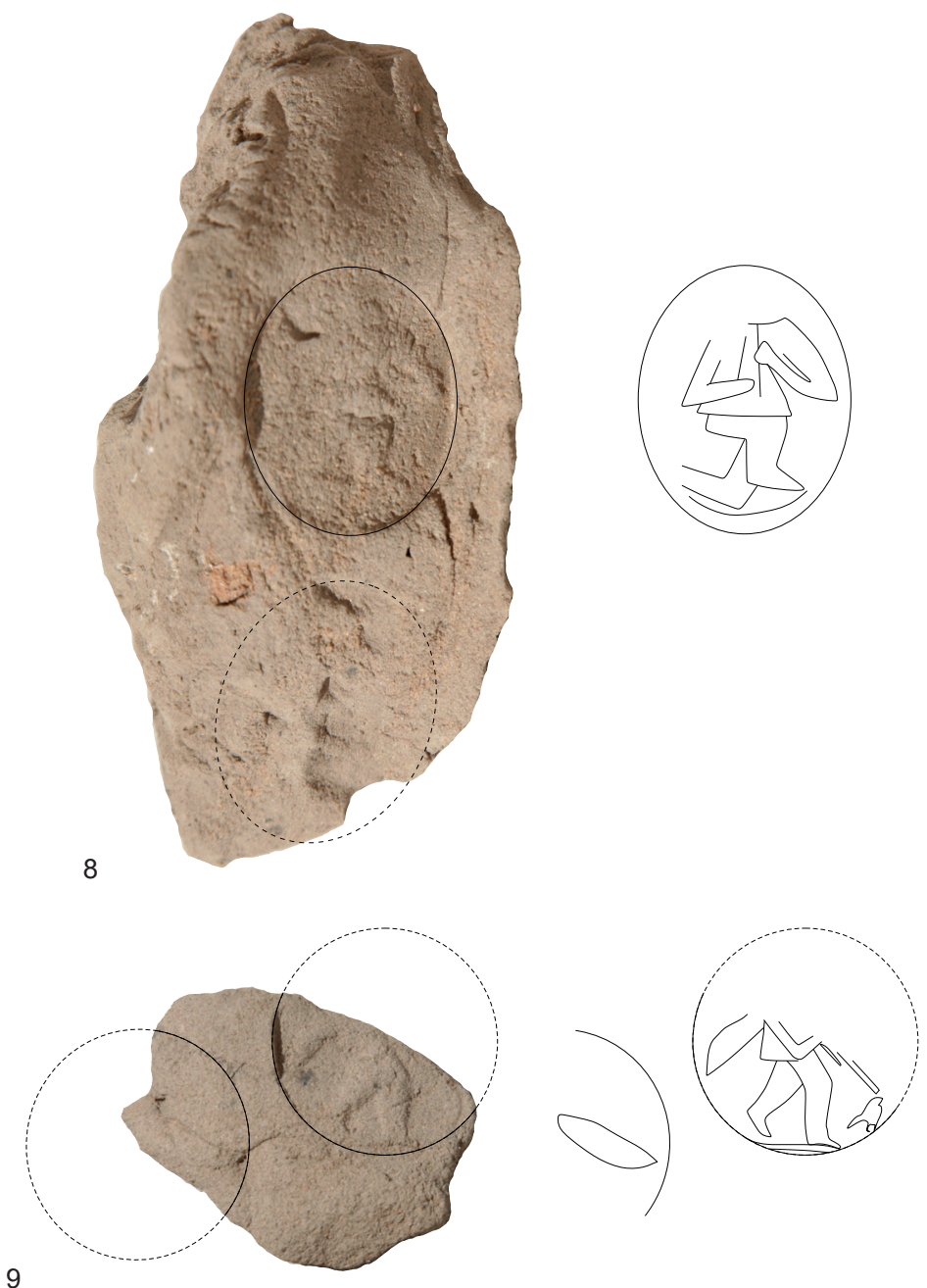

9

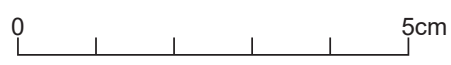

5. Sealings with stamp impressions (cat. nos 7-9) from Selib 2, S2/1/2010 (Phot. K. Molga; drawing: R. Hajduga). 

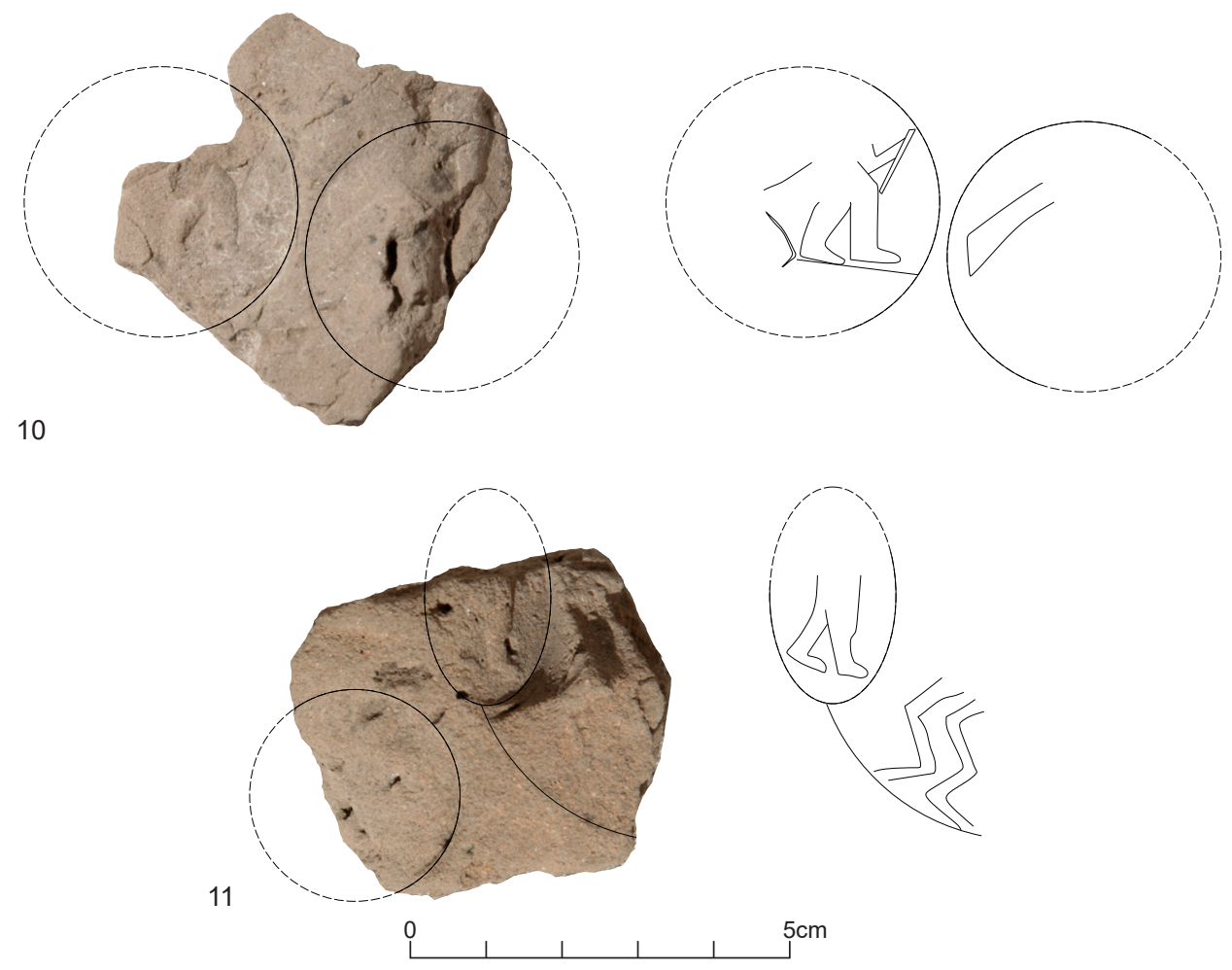

6. Sealings with stamp impressions (cat. nos 10-11) from Selib 2, S2/1/2010 (Phot. K. Molga; drawing: R. Hajduga).

cat. no. 11

shape: oval; dimensions: 1.8 x $1.5 \mathrm{~cm}$ (preserved fragmentarily).

Description: a walking figure facing right. Although the upper part of the body is not preserved, it is possible to distinguish a few features. The legs are spaced apart, the toes point right, and a short robe falls over the knee. This sealing is stamped with at least two different stamp seals. On the right from the cat. no. 11, there are two horizontal zigzag stripes, which could be an imprint of a basket or cloth. The impression of the sealing on the left is unclear.

cat. no. 12

shape: oval; dimensions: $3.7 \times 2.5 \mathrm{~cm}$.

Description: a walking winged figure facing right. He is shown with widely spaced legs and arms bend at the abdomen level. A flat-topped headgear is visible on the head, with a ribbon or piece of material flowing from his back, perhaps a fragment of the royal cap. There is a small object attached to his chin, perhaps a false beard, and ornamented clothes or jewellery around his neck. The figure holds a bludgeon or mace, leaning against his 


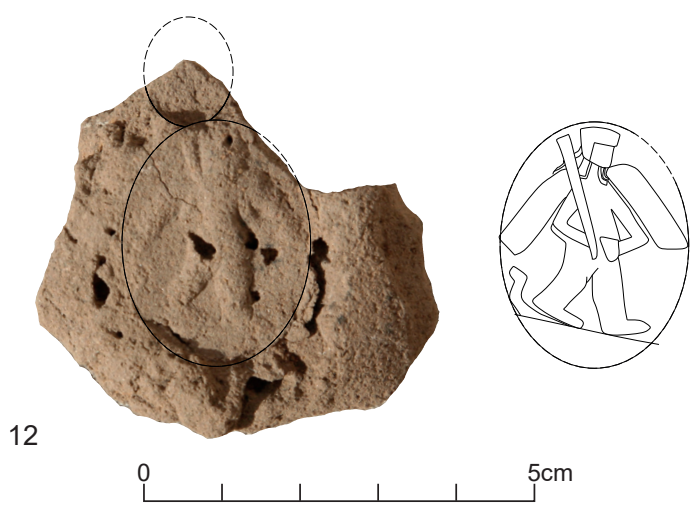

7. Sealing with stamp impression (cat. no. 12) from Selib 2, S2/1/2010 (Phot. K. Molga; drawing: R. Hajduga).

right arm. In the other hand, he holds an unidentified squarish object. Behind the figure and under the leg, there is an uraeus. On the same sealing and above cat. no. 12 is another stamp impression, but the image inside the field is unclear.

Commentary: A headgear resembles the close-fitting helmet or a cap worn by Kushite rulers. ${ }^{17} \mathrm{~A}$ false beard was worn by royalty as a sign of sovereignty. Both attributes, therefore, suggest that a pharaoh is represented on this impression. Standing winged figure with a sceptre is known from the seal impression found at Kerma. However, the figure faces left and does not have any crown or headgear in this case. ${ }^{18}$

cat. no. 13

shape: oval; dimensions: 3.75 x $2.2 \mathrm{~cm}$ (preserved fragmentarily).

Description: walking winged figure, facing right. The arms are bent at the abdomen level, while long wings project from the back. The figure wears headgear with an uraeus at the front and a schematically presented hemhem crown above. On the chin a band is visible, perhaps part of the headgear. The figure holds a long sceptre that ends with a sun disk, or the disk itself is placed behind him. He stands on the elongated body of an uraeus with raised head. The second impression of the same stamp is visible above the first one, but only the lower part of the field with the legs of a figure is preserved. There are four stamp impressions on this sealing, but only one is preserved completely.

cat. no. 14

shape: oval; dimensions: $2.5 \times 1.8 \mathrm{~cm}$.

Description: a walking winged figure facing right. He is wearing a short robe, legs are widely spaced, while arms bend at chest level. A flat-topped headgear is visible on the head and resembles a close-fitted cap or helmet worn by rulers (see cat. no. 12). In the right

\footnotetext{
17 Leahy 1992: 232-239.

18 Ruffieux 2007: 245, P1. 1, Fig. 9.
} 

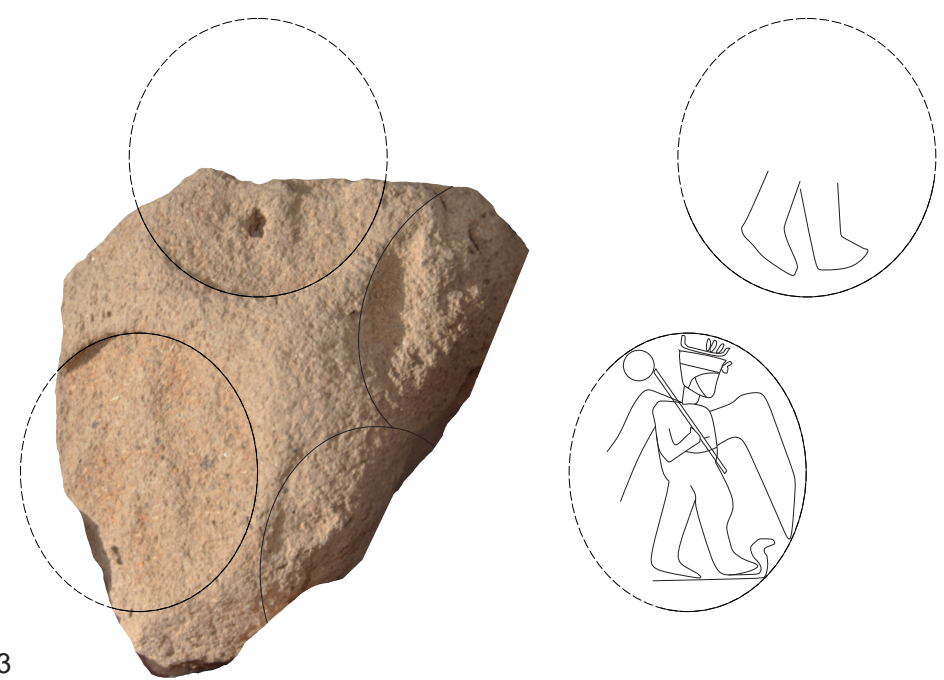

13

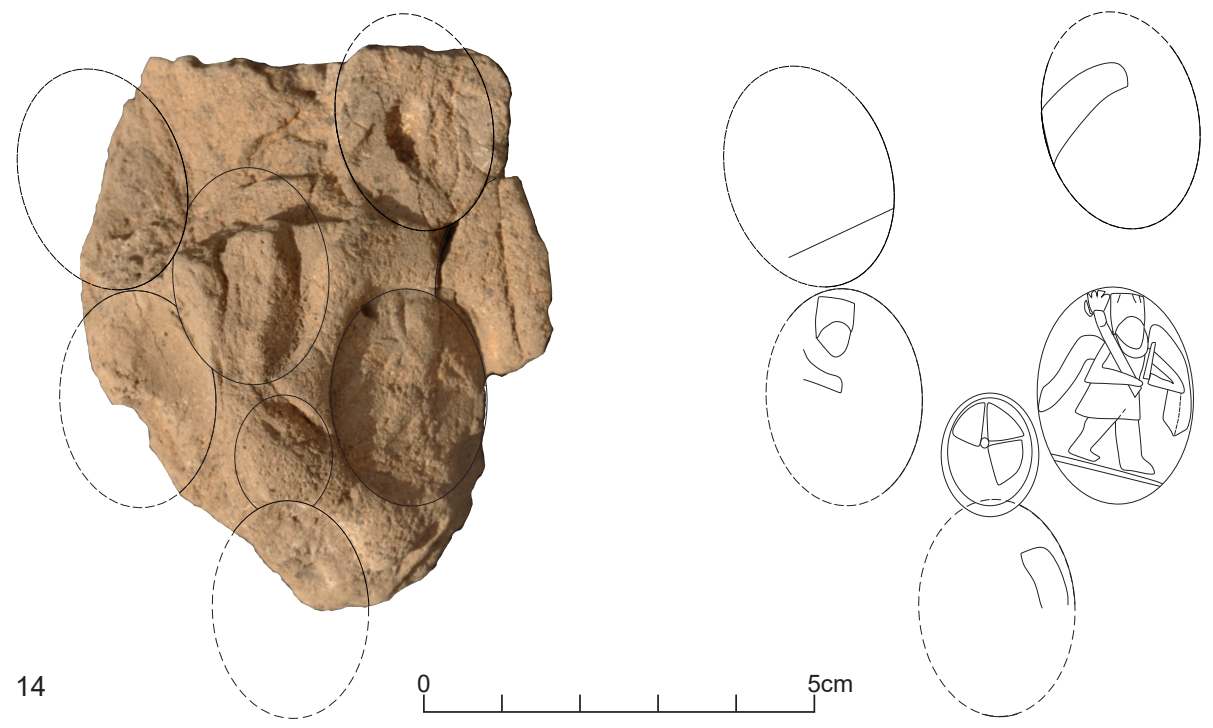

8. Sealings with stamp impressions (cat. nos 13-14) from Selib 2, S2/1/2010 (Phot. K. Molga; drawing: R. Hajduga).

hand, the figure is holding a bludgeon or mace. In the left hand he holds a stick or a spear. Commentary: similar to cat. no. 12 .

cat. no. 15

shape: circular; dimensions: d. $3.1 \mathrm{~cm}$.

Description: a walking winged figure facing right. The arms are bent at the abdomen level; the legs are widely spaced while long wings project from the back. Details are unclear, 

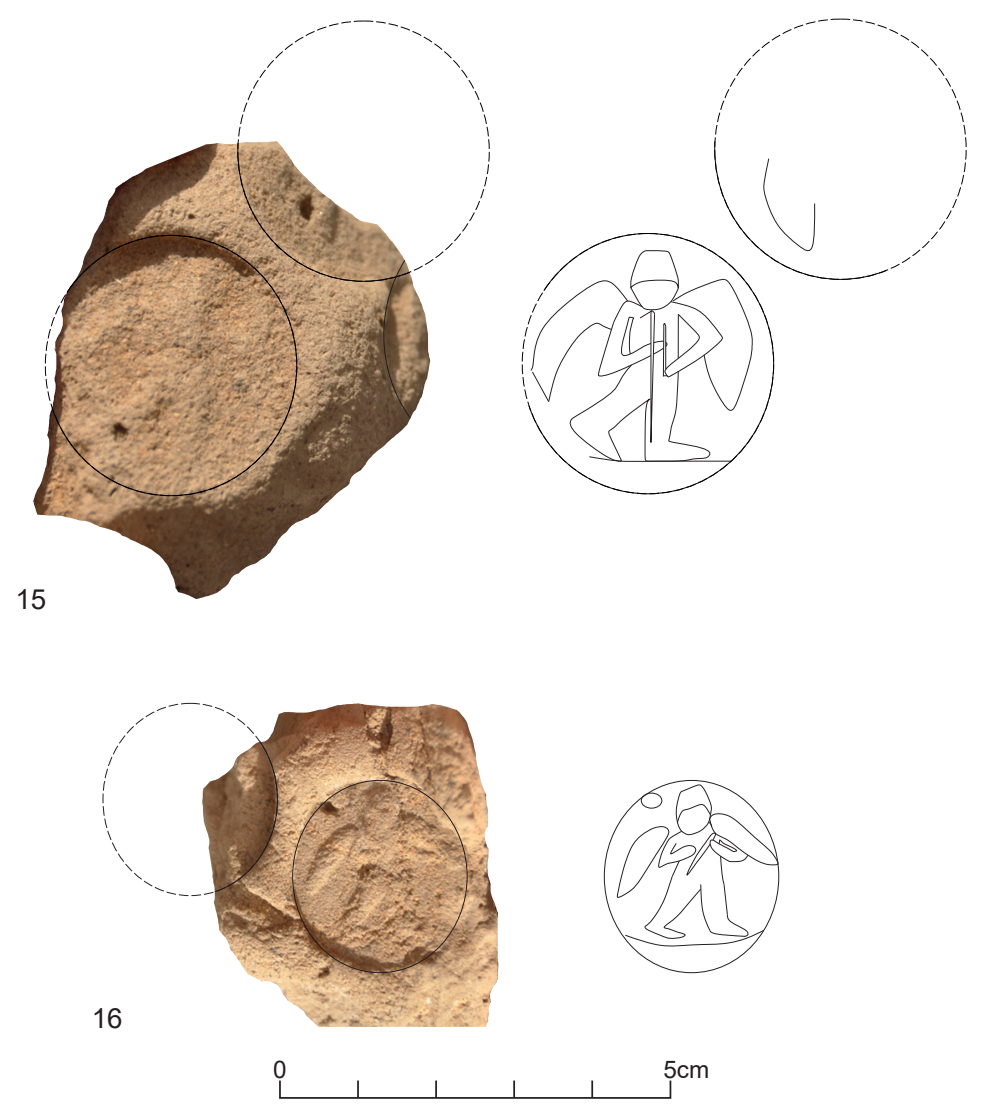

9. Sealings with stamp impressions (cat. nos 15-16) from Selib 2, S2/1/2010 (Phot. K. Molga; drawing: R. Hajduga).

but close-fitted headgear and two objects held in both hands can be recognised, perhaps a sceptre and a spear. The stamp was impressed on the sealing twice. Only a small fragment of the second impression is preserved with a small part of a left wing.

Commentary: similar to cat. no. 12 and 14 .

cat. no. 16

shape: circular; dimensions: d. $2.3 \mathrm{~cm}$.

Description: a walking winged figure facing right, with a sun disk to the left of the head. The arms are bent at chest level, fists are clenched, perhaps because an attribute (a sceptre?) is held in the hands. Long and outstretched wings project from the back. On the head of the figure is a cap crown of a form usually associated with the king or a deity. The stamp was impressed twice on this sealing.

Commentary: similar to cat. no. 13. The image of the ruler with the wings and a solar disk refers to the elements of the solar cult. 

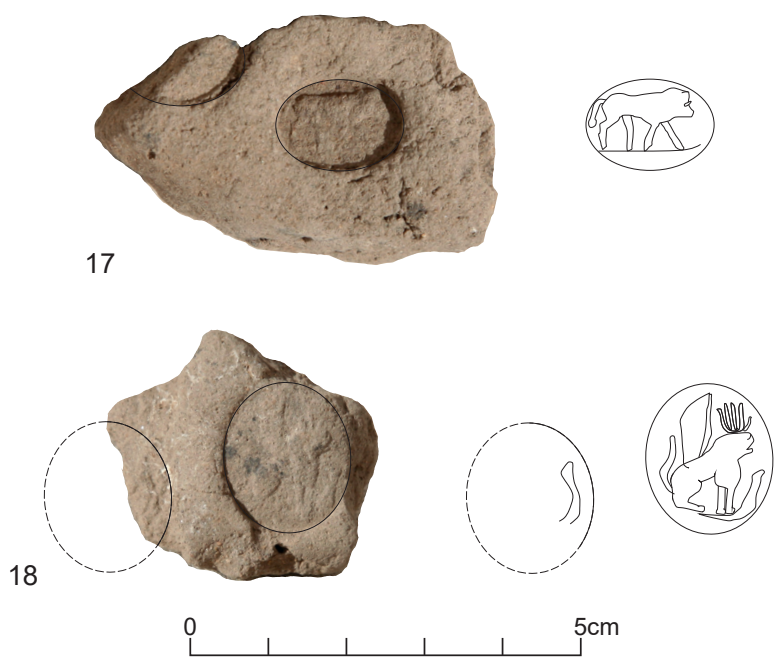

10. Sealings with stamp impressions (cat. nos 17-18) from Selib 2, S2/1/2010 (Phot. K. Molga; drawing: R. Hajduga).

cat. no. 17

shape: oval; dimensions: $1.8 \times 1.4 \mathrm{~cm}$.

Description: a walking wild boar occupy the field. The boar facing right stands on a flat base. The thin and hoofed legs characteristic for this animal, alongside a hairbrush-ended tail, pointed ears, and an elongated snout with a flat nose and sharp tusks can be distinguished. This stamp was twice impressed on the same stopper.

Commentary: the image corresponds to JB31 from Jebel Barkal. ${ }^{19}$

cat. no. 18

shape: oval; dimensions: 1.7 x $1.4 \mathrm{~cm}$.

Description: a seated gryphon occupies the field. The figure combines a lion's body with the wings. It is standing on a cobra with a raised head. On the gryphons head is a hemhem crown, but the sealing surface is degraded at this spot and details are illegible. The manner of representing the gryphon face, with marked nostrils, indicates the stamp maker's attention to detail and considerable craftsmanship. This image is repeated twice on the same sealing. Commentary: The details and attributes of the figure associate it with the god Apedemak. Parallel representations are known from a graffito on the wall of the Great Enclosure in Musawarat es-Sufra ${ }^{20}$ and a relief on a column in the interior of the Lion Temple in Musawwarat Es-Sufra. ${ }^{21}$ Moreover, this image corresponds to the sealings from Jebel Barkal with sitting winged Apedemak with hemhem crown on its head (JB3, JB4, JB5). ${ }^{22}$

\footnotetext{
19 Vincentelli 1992: 120.

20 Kleinitz 2014.

21 Wenig 1978: 80, Fig. 56.

22 Vincentelli 1992: 109.
} 


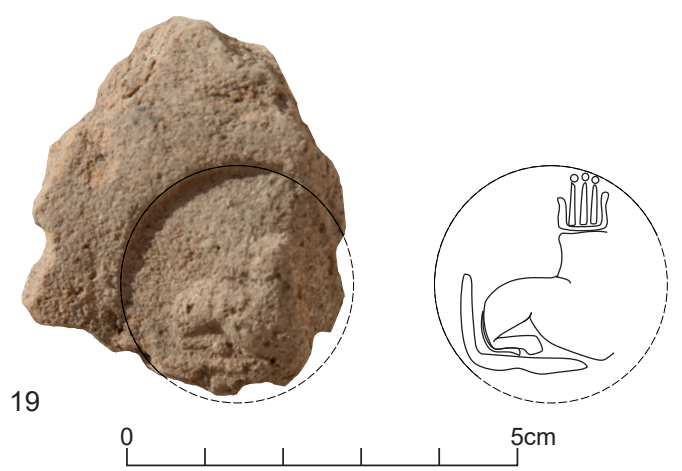

11. Sealing with stamp impression (cat. no. 19) from Selib 2, S2/1/2010 (Phot. K. Molga; drawing: R. Hajduga).

cat. no. 19

shape: circular; dimensions: 2.4 x $1.9 \mathrm{~cm}$ (preserved fragmentarily).

Description: a lying lion with the body facing right but the head in frontal view. The body's shape, paws and head with characteristic ears resemble the typical Meroitic manner of representing a lion. ${ }^{23}$ The animal is lying on a flat base. The hemhem crown on the head identifies the figure with the god Apedemak.

Commentary: The image resembles a seal impression from Jebel Barkal (JB8), ${ }^{24}$ and corresponds to the impression of the bazel from Meroe. ${ }^{25}$

cat. no. 20

shape: circular; dimensions: 1.5 x $1 \mathrm{~cm}$ (preserved fragmentarily).

Description: a rear leg of a sitting lion facing right. Thick paws and curled tail are preserved. Commentary: This image resembles a sealing impression from Jebel Barkal (JB2). ${ }^{26}$

cat. no. 21

shape: oval; dimensions: 1.7 x $1.1 \mathrm{~cm}$ (preserved fragmentarily).

Description: a walking lion facing right with clearly defined paws, claws and a muscled body. It seems that the base on which the animal walks is part of the elongated cobra with raised head. Due to the accurate rendering of the details, the impression has a unique character and demonstrates the high skills of the seal maker.

Commentary: It resembles a seal impression from Jebel Barkal (JB7). ${ }^{27}$

\footnotetext{
23 Priese 1992: 25.

24 Vincentelli 1992: 112.

25 Žabkar 1975: P1. XXVIb.

26 Vincentelli 1992: 109.

27 Vincentelli 1992: 109.
} 

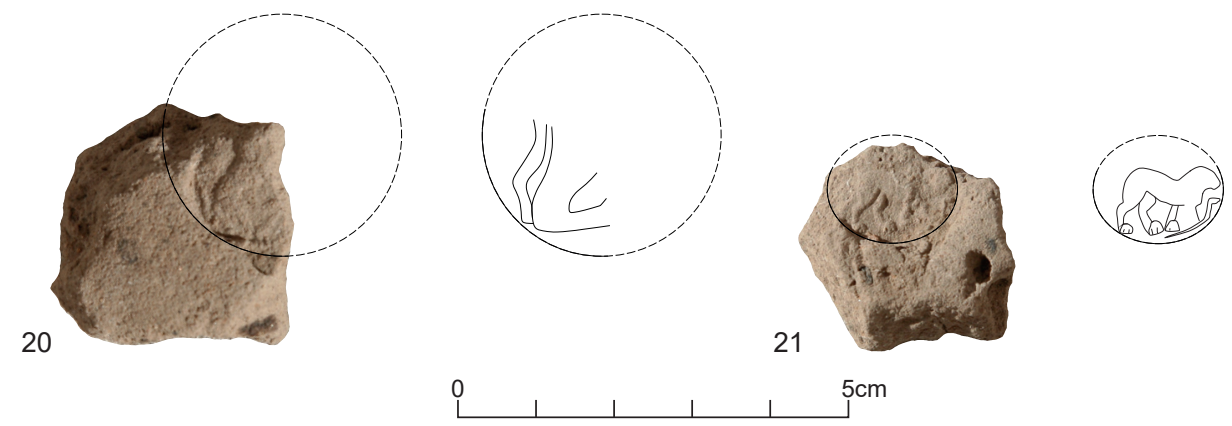

12. Sealings with stamp impressions (cat. nos 20-21) from Selib 2, S2/1/2010 (Phot. K. Molga; drawing: R. Hajduga).

cat. no. 22

shape: oval; dimensions: 1.4 x $0.8 \mathrm{~cm}$.

Description: a standing lion facing right with a solid and muscular body and legs with thick paws. The thick and long mane on the animal's neck, mouth, nostrils, and even its ear are marked. The details are accurately rendered, and the image is of high craftsmanship. The lion walks on a curved base or probably on elongated uraeus, whose raised head is visible in front of the animal. Above the lion is a winged solar disk adjusted to the field's curve. This image is repeated seven times on the same sealing, but the impressions are in different state of preservation.

Commentary: see cat. no. 21. The lion under the winged solar disk can be associated with Apedemak.

cat. no. 23

shape: circular; dimensions: 3.2 x $2.9 \mathrm{~cm}$ (preserved fragmentarily).

Description: a sitting lion facing right. The lion has a crown on the head. In front of him is an uraeus, possibly with a sun disk above his head. Above the hindquarters of the lion a winged sun disk could be noted. The seal was twice impressed on the sealing.

Commentary: This image resembles seal impressions from Jebel Barkal (JB3, JB6). ${ }^{28}$ It also corresponds to the seal impression found in the North Cemetery at Meroe (no. 474), on which the seated lion is facing left. ${ }^{29}$ An interesting parallel comes from stopper (inv. no. F775) found in the palace of Natakamani in Napata, with an image of two seated lions. ${ }^{30}$

cat. no. 24

shape: oval; dimensions: $1.3 \times 1 \mathrm{~cm}$.

Description: a crocodile with an elongated body and a muscular tail, standing on a flat base. Legs are tucked under the belly, and the feet end in claws. Three birds, possibly hawks,

\footnotetext{
28 Vincentelli 1992: 109.

29 Dunham 1957: 173-174, Fig. 114.

30 See online image: Diffendale 2020.
} 

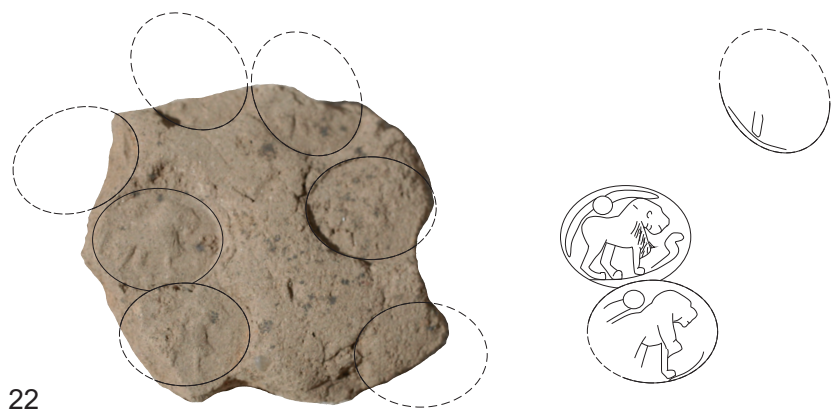

22

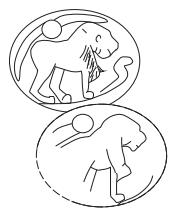

23
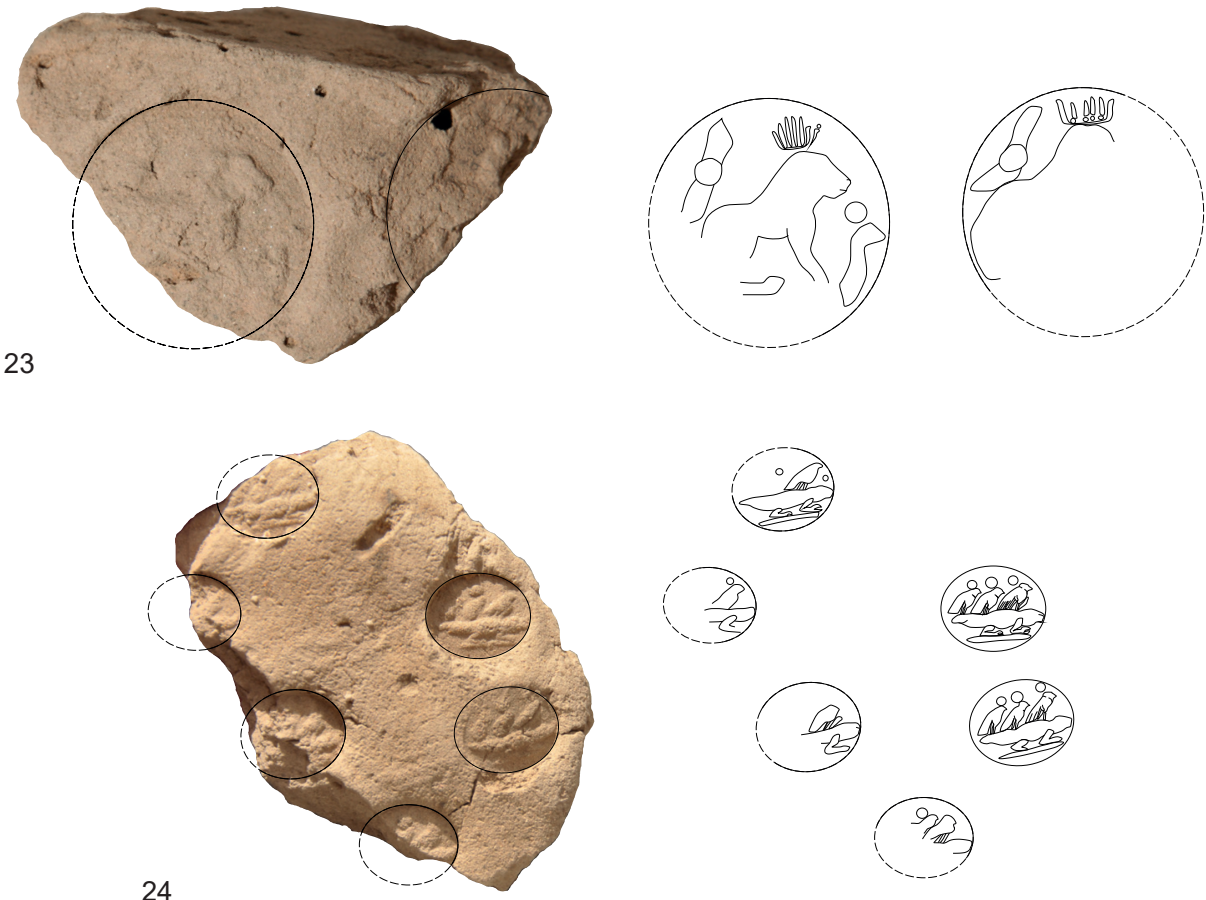

24

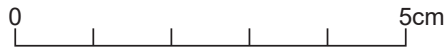

13. Sealings with stamp impressions (cat. nos 22-24) from Selib 2, S2/1/2010 (Phot. K. Molga; drawing: R. Hajduga).

with sun disks over their heads, sit on its back. There is an unclear object in front of the first bird - possibly an uraeus. This stamp is repeated six times on the sealing. Commentary: The crocodile is rarely attested on Meroitic seals. It is represented on a bronze pendant seal from Meroe, on which a crocodile is shown with a ram-headed sphinx. ${ }^{31}$

31 Welsh 2002: 245-246. 

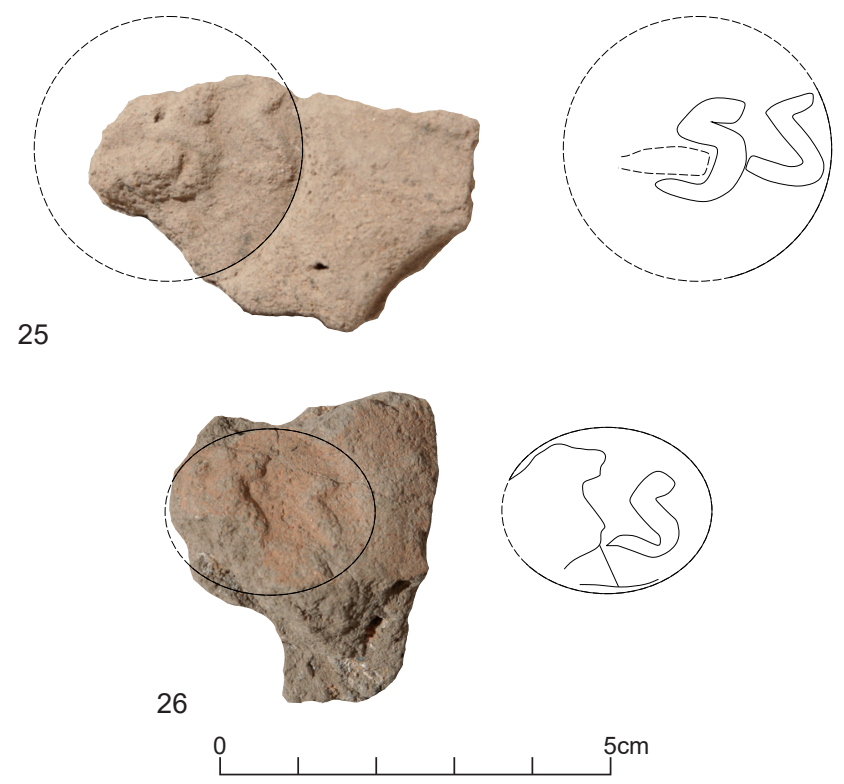

14. Sealings with stamp impressions (cat. nos 25-26) from Selib 2, S2/1/2010 (Phot. K. Molga; drawing: R. Hajduga).

cat. no. 25

shape: circular; dimensions: $2.5 \mathrm{x} 2 \mathrm{~cm}$ (preserved fragmentarily).

Description: two cobras facing right. Behind the cobras is an unidentified rectangular shape that may be part of the leg of a lion or human figure or the body of another cobra. Commentary: A similar depiction appears on a scarab from Amara West..$^{32}$ It shows a row of four cobras with sun disks above their heads below an image of a scorpion and a fish. It cannot be excluded that two cobras from cat. no 25 were part of a larger composition, e.g. of three cobras. Such an image could be found on a heart-scarab seal from Medinet Habu. ${ }^{33}$ According to Étienne Drioton, this was a trigramme of Amun. ${ }^{34}$ However, it is not certain if the discussed seal impression from Selib 2 had a character of cryptographic writing and express the name Amun.

cat. no. 26

shape: oval; dimensions: $2.5 \times 1.8 \mathrm{~cm}$ (preserved fragmentarily).

Description: a sitting lion and a cobra facing right. The details of the lion are hardly legible, but his head, front legs and the arched base on which the animal is sitting are visible. Traces of red pigment could be recognised on the surface.

\footnotetext{
32 Spencer, Stevens, Binder [2014]: 47-48.

33 Teeter, Wilfong 2003: P1. 44.

${ }^{34}$ Drioton 1957: 18.
} 


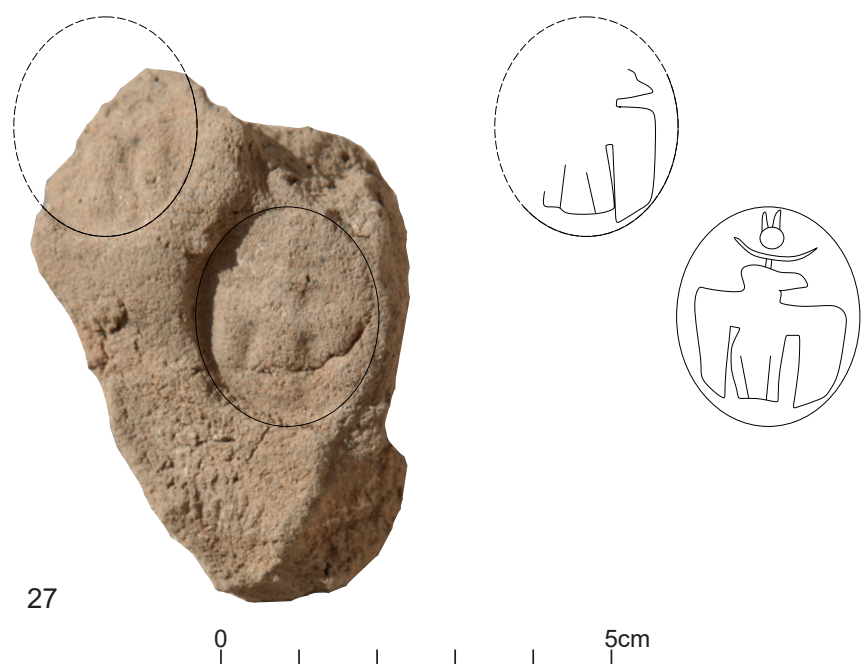

15. Sealing with stamp impression (cat. no. 27) from Selib 2, S2/1/2010 (Phot. K. Molga; drawing: R. Hajduga).

Commentary: This image might have been somehow similar to cat. no. 25 , but the state of preservation of both seal impressions makes the comparison impossible.

cat. no. 27

shape: oval; dimensions: $2.4 \times 1.9 \mathrm{~cm}$.

Description: schematically outlined bird, with broad, slightly spread wings, head turned to the right and large beak. The bird has headgear, which is indistinct due to the abrasion of the sealing surface. It could be a single atef with a sun disk or hemhem crown. The image is repeated twice on the sealing, but only one impression is legible.

Commentary: The hemhem crown is known from sealings from Jebel Barkal (JB16 and JB17). ${ }^{35}$

cat. no. 28

shape: oval; dimensions: $1.6 \times 1.4 \mathrm{~cm}$.

Description: a slim bird facing left standing on a flat base, perhaps a branch, with clearly marked claws, legs and a feathered tail. The bird's posture and proportions suggest that this could be a hawk. Only one stamp impression was found on this fragmentary sealing. Commentary: A very similar representation comes from scarab stamp from Amara West, from the grave G234. ${ }^{36}$ It also resembles a seal impression from Jebel Barkal (JB29). ${ }^{37}$

\footnotetext{
35 Vincentelli 1992: 114.

36 Spencer, Stevens, Binder [2014]: 49.

37 Vincentelli 1992: 117.
} 

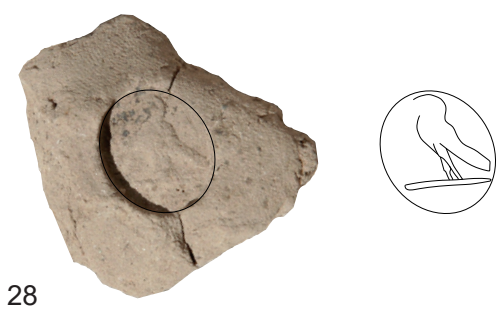

29
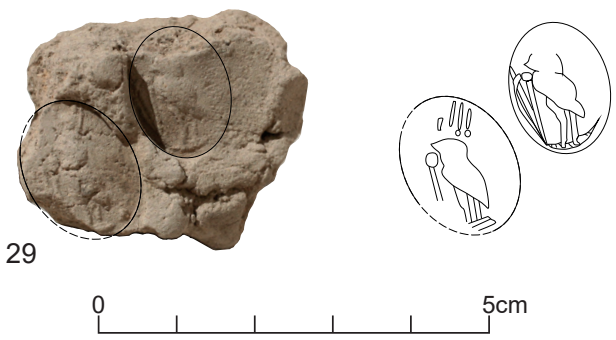

16. Sealings with stamp impressions (cat. nos 28-29) from Selib 2, S2/1/2010 (Phot. K. Molga; drawing: R. Hajduga).

cat. no. 29

shape: oval; dimensions: 1 x $0.8 \mathrm{~cm}$.

Description: a bird facing left standing on a curved base, perhaps a bow. Possible lotus flowers or a tree and a sun disk are visible in front of the animal. The bird has slender legs and tail and should probably be interpreted as a hawk. A sun disk and two feathers on the head suggest that this could be Horus. This stamp is repeated twice on the sealing. Commentary: This image is very similar to cat. no. 28 (see there for further analogies). A comparable representation of Horus is known from Muewis, and it shows a hawk with a hemhem crown standing in front of a symbol of a sacred tree. ${ }^{38}$ An example of deity sitting under the sacred tree is known from Gamai, from the impression of a bazel of the silver ring showing lion-god Apedemak. ${ }^{39}$

cat. no. 30

shape: oval; dimensions: 1.4 x $1 \mathrm{~cm}$.

Description: a rosette or an ankh sign, placed in a circle. This stamp is twice impressed on the sealing.

Commentary: The symbol of ankh is borrowed from the iconography of Egypt. An elaborated version of this symbol crowned with feathers is known, for example, from a gold ring seal from Meroe. ${ }^{40}$ This symbol is widely attested among seal impressions and seals

\footnotetext{
38 Baud, Sackho-Autissier, Labbé-Toutée 2010: 92, Fig. 96.

39 Žabkar 1975: P1. XXVIa.

40 Priese 1992: 40, Fig. 38b.
} 

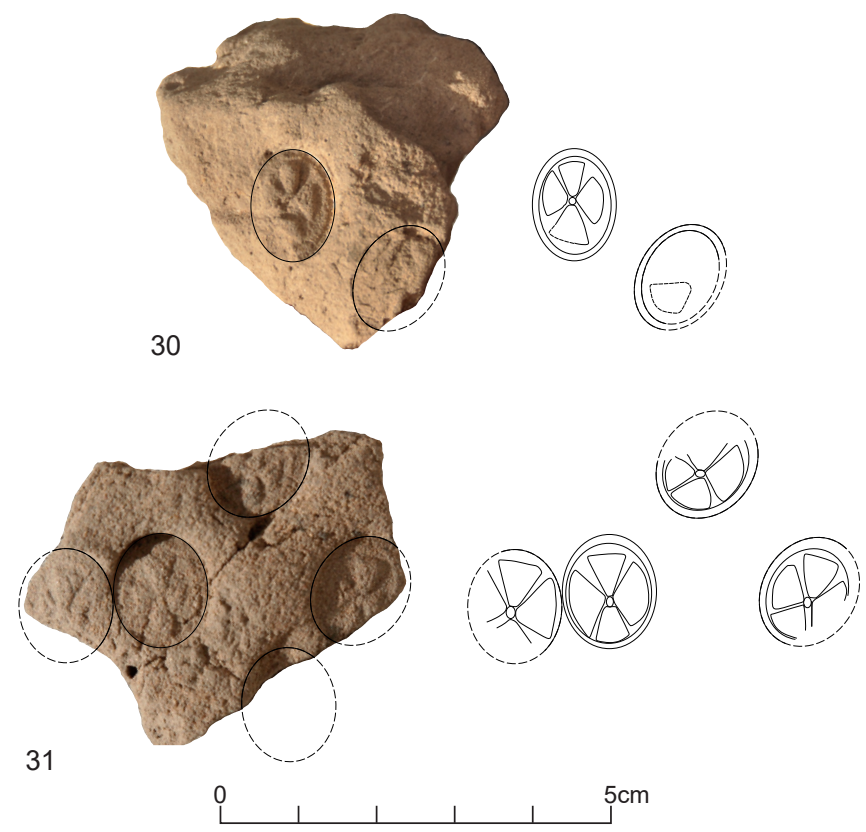

17. Sealing with stamp impressions (cat. nos 30-31) from Selib 2, S2/1/2010 (Phot. K. Molga; drawing: R. Hajduga).

from Meroe and Jebe Barkal. ${ }^{41}$ Sealings of this type were also found in temple T in Kawa. ${ }^{42}$ See also: cat. nos 14 and 31 .

cat. no. 31

shape: oval; dimensions: $1.5 \times 1.2 \mathrm{~cm}$.

Description: a rosette or an ankh sign occupies the field. The same stamp is five-times impressed on the sealing.

Commentary: see cat. nos 14 and 30.

\section{CONCLUSIONS}

The seals impressed on sealings from Selib 2 have oval or round forms and they are quite uniform in size. The seals themselves must have been made of stone and faience and could have taken the form of a scarab, ${ }^{43}$ cylinder, cone or signet-ring. ${ }^{44}$ In fact, a scarab stamp seal with a geometric pattern was found in S2/1/2010 (Fig. 18a). ${ }^{45}$ In Kerma, the sealings

\footnotetext{
41 Dunham 1965.

42 Macadam 1955: 186-187.

43 Horn 1973: 281-288.

44 Vincentelli 1992: 108.

${ }^{45}$ Hajduga, Solarska 2015: 392-393.
} 

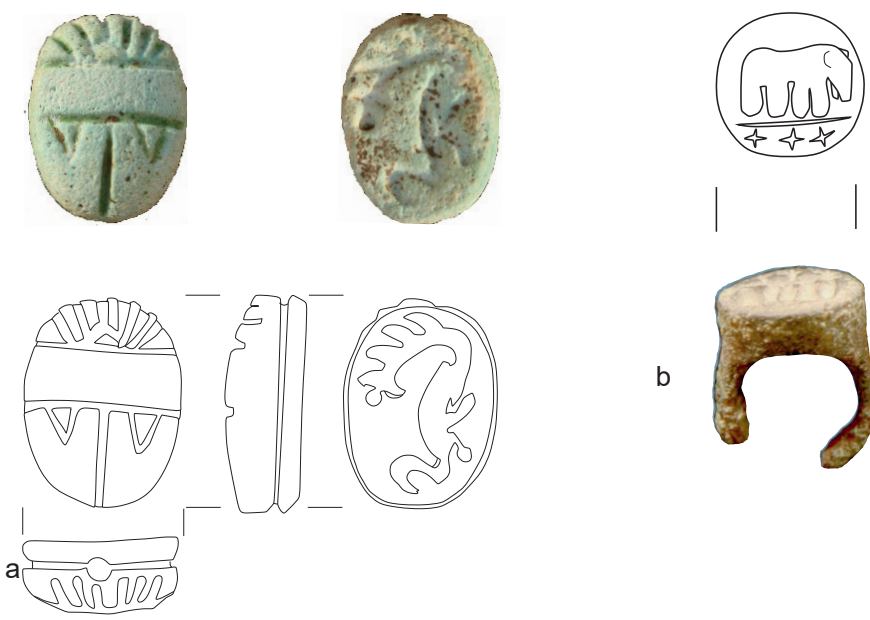

b
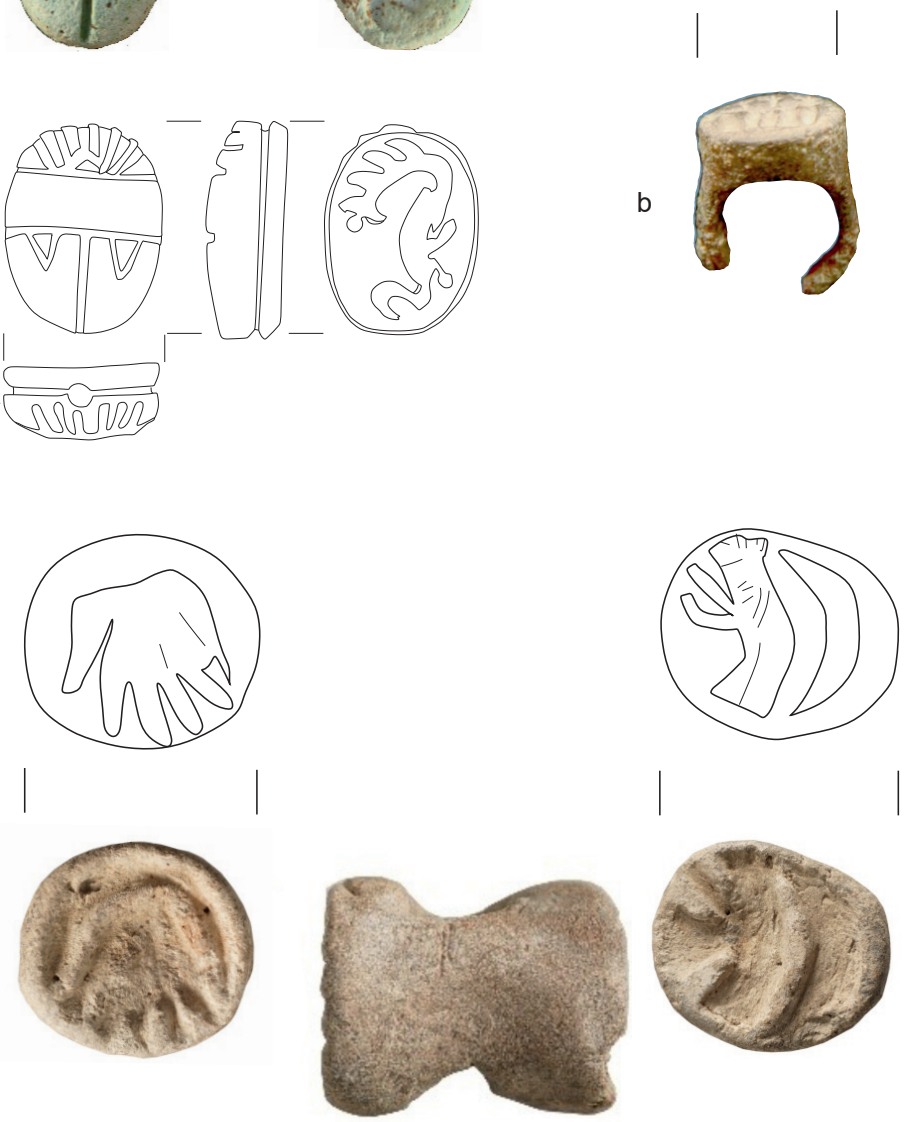

c
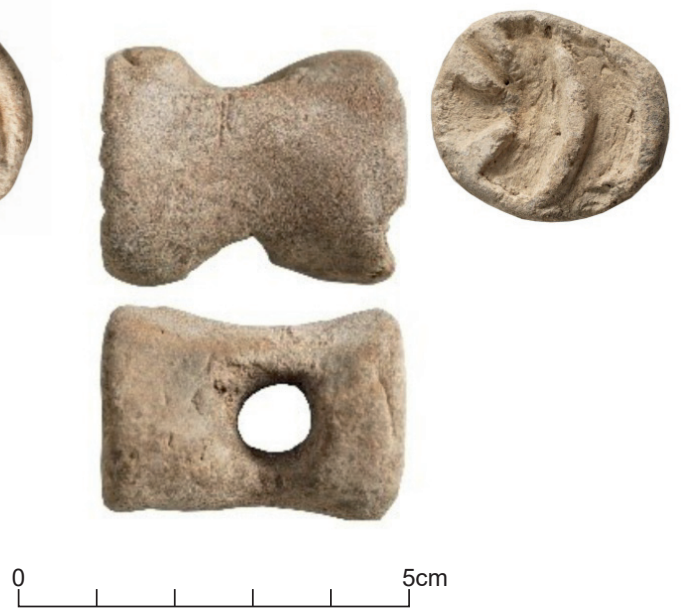

18a-c. Stamp seals from Selib 2 (Phot. K. Molga, drawing. R. Hajduga). 
and scarab stamp seals are attested simultaneously in Western Deffufa. ${ }^{46}$ Moreover, the design on a scarab stamp from Amara West ${ }^{47}$ matches the cat. no. 29 from Selib 2. All this together suggest that some impressions from Selib 2 were made by this type of stamps. To other seals attested at Selib 2 belong a bronze signet-ring (Fig. 18b), a stray find from the 2010 season, with the image of an elephant. ${ }^{48}$ A cylindrical seal with stamps on two opposite sides was found in 2019 (Fig. 18c). It probably also shows the image of an elephant. ${ }^{49}$

Sealings included in the catalogue have one or multiple impressions of the same (e.g. cat. nos 22,24$)$ or different seals (e.g. cat. no. 14). The impressions combine figural and nonfigural motifs. They seem to be ornamental rather than signs of a formal writing system. Among figural images, anthropomorphic (cat. nos 1-16) and zoomorphic (cat. nos 17-29) representations could be distinguished, executed with care for details of human and animal figures. The first group included images of walking, standing or kneeling figures in iconographical terms resembling a pharaoh: they could wear the crown of Upper and Lower Egypt and royal sceptres. One of the figures wears a hemhem crown (cat. no. 13), depicted also on four zoomorphic representations (cat. nos 18-19, 23, 29). This ceremonial headgear with a triple atef, ram's horns and uraei are known from Egypt and has been adopted in Meroitic Nubia. Though often worn by deities, it could also be an attribute of a king. The figures often held a mace (cat. nos 12,14), spear (cat. no. 4) or a sceptre (cat. nos $1,2,5,10,13,16$ ). In one case, the figure holds a bow (cat. no. 3). Such depictions of a pharaoh or a god is common in Kushite art. Apedemak is often shown with a bow, sword or sceptre swinging at enemies, e.g. in the Lion Temple in Musawwarat es-Sufra. ${ }^{50}$

The zoomorphic representations include crocodiles, birds, lions, wild boars, and fantastic creatures, such as gryphon. To non-figural motifs belongs ankh sign (or a rosette), found on three sealings from the studied group (cat. nos 14, 30,31). Generally, motifs from seal impressions found at Selib 2 showing a similarity to those found in Egypt demonstrate cultural influences from this region in the Dongola Reach, and perhaps mutual commercial contacts.

Stamps impressions from Selib 2 possibly refer to production, distribution and ownership. Sealings were vital for controlling the flow of goods within Upper Nubia. However, their function was not restricted to the process of distribution of food and goods for daily consumption on a local scale. An example of this phenomenon could be the scarab stamp seal from Amara West,$^{51}$ with an image having parallels in the collection from Selib 2 (cat. nos 28-29). This indicates a commercial relationship of Selib 2 with the North, perhaps redistribution or trade on the supra-regional scale, with Egypt or beyond.

\footnotetext{
46 Wegner 2018: 242, Fig. 3.7.

47 Spencer, Stevens, Binder [2014]: 49.

48 Żurawski et al. 2013: 292.

49 Hajduga, Momot, Łopaciuk 2021.

50 Žabkar 1975: Pls XVI-XVII, XX.

51 Spencer, Stevens, Binder [2014]: 49.
} 
Further evidence in this respect is provided by seal impressions from Kerma, with names of pharaohs from the Middle Kingdom Egypt. ${ }^{52}$ This phenomenon is also illustrated by impressions of seventeen stamps bearing the name of Thutmose III on a clay ball from Sai Island.$^{53}$ The names Thutmose III and Hatshepsut were also found on sealings from a small warehouses near the temple of Amun at Amara West. ${ }^{54}$

Sealings were undoubtedly widely used for closing vessels as well as in other administrative practices. The findspot of the discussed collection from Selib 2 and their distribution among the storage vessels defines S2/1/2010 building as a storehouse: a place where goods were stored, unpacked or transhipped and marked with another sealing. Moreover, fragments of imported amphorae were discovered in the same building, including sixteen sherds from room 1, identified as imports from Aswan based on fabric analysis. These suggest a place of origin for goods transported in containers closed by the studied sealings and possibly the origin of some of the sealings. Since both the sealings and amphorae fragments came from the same contexts, it can be assumed that the sealings were thrown away after opening these containers. Besides storage purposes, the building probably also had administrative functions, and this was also a place for food production and consumption. From the number of sealings from this building alone, we cannot determine the scale or scope of goods arriving at Selib 2. It should also be considered that some sealing fragments were found in the mortar between the bricks. Therefore they were reused and perhaps originated from an earlier structure located in the same place or nearby. Perhaps a rebuild or reconstruction of the warehouse or even foundation of a new one was carried out because the trade had expanded and increased in range.

\section{References}

Baud, M., Sackho-Autissier A., Labbé-Toutée, S. 2010: Méroé: Un empire sur le Nil, Paris

Budka, J. 2017: Life in the New Kingdom town of Sai Island: Some new perspectives, [in:] Spencer, N., Stevens, A., Binder, M. (Eds), Nubia in the New Kingdom. Lived experience, pharaonic control and indigenous traditions, British Museum Publications on Egypt and Sudan 3, Leuven-Paris-Bristol, 429-447

Diffendale, D. 2020: Cretula with stamp-seal impression from Napata, https://www.flickr.com/ photos/dandiffendale/50001427412/in/photostream/ (accessed June 11, 2021)

Drioton, É. 1957: Trigrammes d'Amon, WZKM 54, 11-33

Dunham, D. 1957: Royal Tombs at Meroë and Barkal, The Royal Cemeteries at Kush IV, Boston

\footnotetext{
${ }^{52}$ Gratien 1991: 22, Pl. I, Fig. 7; 1993: Fig. b on page 40.

${ }^{53}$ Budka 2017: 437.

${ }^{54}$ Spencer, Stevens, Binder [2014]: 17.
} 
Dunham, D. 1965: A Collection of 'Pot-Marks' from Kush and Nubia, Kush XIII, 131-147

Gratien, B. 1991: Empreintes de sceaux et administration à Kerma (Kerma Classique), Genava n.s. 39, 21-24

Gratien, B. 1993: Nouvelles empreintes de sceaux à Kerma: Aperçus sur l'administration de Kouch au milieu du $2^{\mathrm{e}}$ millénaire av. J.-C., Genava n.s. 41: 39-44

Hajduga, R., Momot, A., Łopaciuk, R. 2021: The archaeological site of Selib 2 in the Dongola Reach. Remarks on season 2019, PAM XXX, 251-271

Hajduga, R., Solarska, K. 2015: Excavations at Selib 2 in 2012, PAM XXIV/1, 389-396

Horn, S.H. 1973: Scarabs and Scarab Impressions from Shechem-III, JNES 32/3, 281-289

Kleinitz, C. 2014: The graffiti of Musawwarat es-Sufra: current research on historic inscriptions, images and markings at the Great Enclosure, SudNub 18, 93-103

Leahy, A. 1992: Royal Iconography and Dynastic Change, 750-525 BC: The Blue and Cap Crowns, JEA 78, 223-240

Macadam, L.M.F. 1955: The Temples of Kawa II. History and archaeology of the site, London

Priese, K.-H. 1992: Das Gold von Meroe, Mainz a/Rhein

Reisner, G.A. 1914: Excavations at Kerma (Dongola-Province) I. A report on the Egyptian Expedition of Harvard University and the Boston Museum of Fine Arts 1913, Z̈̈S $52,34-39$

Ruffieux, Ph. 2007: Empreintes de sceaux et bouchons de jarres d'époque napatéenne découverts à Doukki Gel (campagnes 2005-2006 et 2006-2007), Genava n.s. 55, 241-246

Spencer, N., Stevens, A., Binder, M. [2014]: Amara West. Living in Egyptian Nubia, London

Teeter, E., Wilfong, T.G. 2003: Scarabs, Scaraboids, Seals, and Seal Impressions from Medinet Habu, OIP 118, Chicago

Vincentelli, I. 1992: A Group of Figurated Clay Sealings from Jebel Barkal (Sudan), Orientalia n.s. 61/2, 106-121

Wegner, J. 2018: The Evolution of Ancient Egyptian Seals and Sealing Systems, [in:] Ameri, M., Costello, S.K., Jamison, G., Jarmer Scott, S. (Eds), Seals and Sealing in the Ancient World. Case Studies from the Near East, Egypt, the Aegean, and South Asia, Cambridge, 229-257

Welsh, F. 2002: A bronze seal from Meroe in the Petrie Museum, London, JEA 88, 243-246

Wenig, S. 1978: Africa in Antiquity II: The Arts of Ancient Nubia and the Sudan. The Catalogue, New York

Žabkar, L.V. 1975: Apedemak, Lion god of Meroe: a study in Egyptian-Meroitic syncretism, Warminster

Żurawski, B. 2000: Dongola Reach. The Southern Dongola Reach Survey, 1998/1999, PAM XI, 209-221

Żurawski, B., Cedro, A., Hajduga, R., Skowrońska, E., Solarska, K., Badowski, T. 2014: Banganarti and Selib: season 2011, PAM XXIII/1, 323-342 
Żurawski, B., Stępnik, T., Drzewiecki, M., Badowski, T., Cedro, A., Molga, K., Solarska, K., Włodarski, T., Hajduga, R. 2013: Banganarti and Selib. Season 2010, With an appendix: Archaeological research report from Selib 2, PAM XXII, 273-294 


\section{ÉTUDES et TRAVAUX XXXIV / 2021}
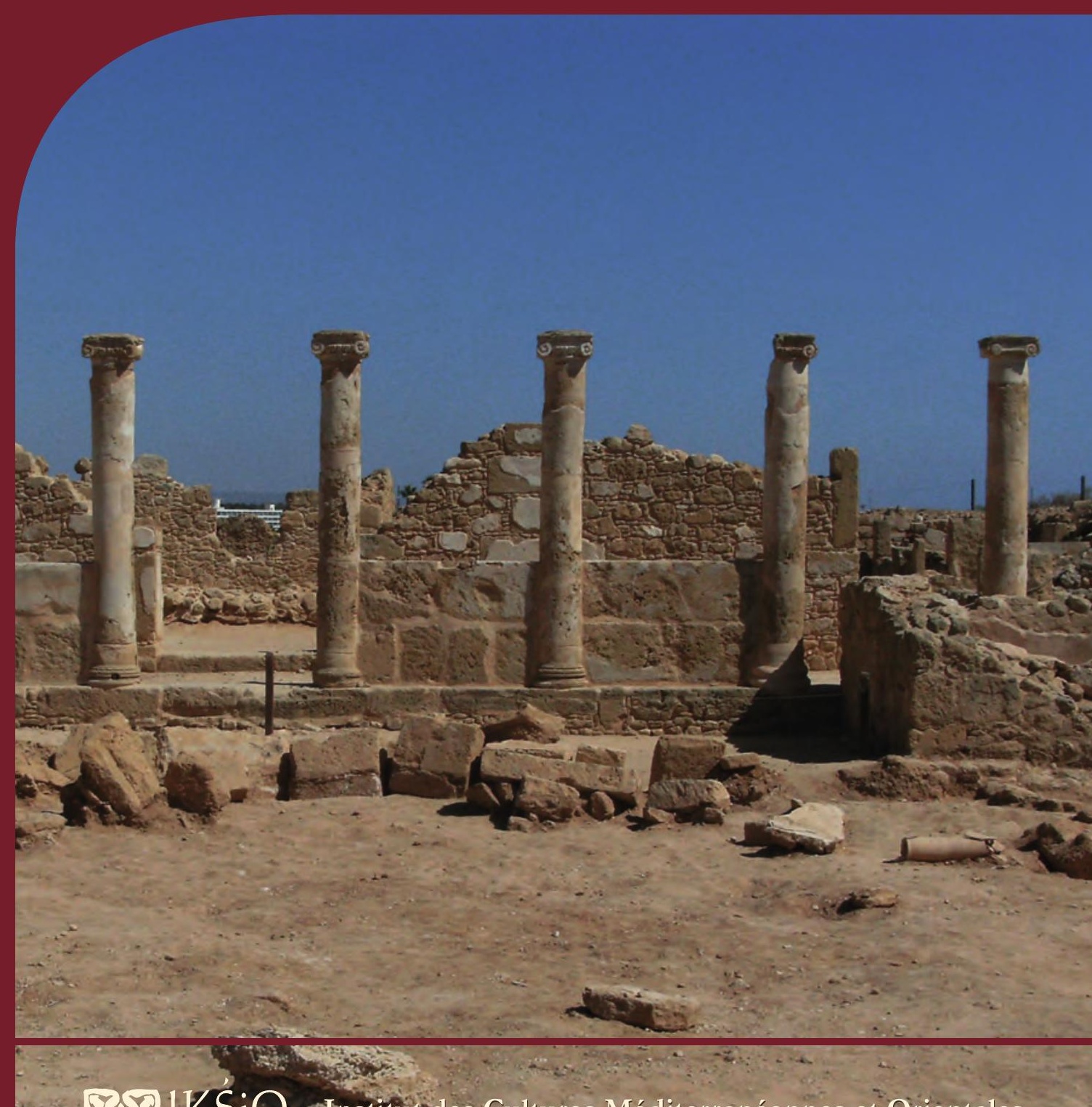

W $92 \mathrm{HKSiO}$ Institut des Cultures Méditerranéennes et Orientales

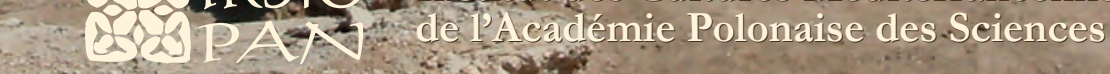

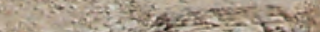

Q 
COMITÉ DE RÉDACTION SCIENTIFIQUE

Maciej Makowski - rédacteur en chef

Jadwiga Iwaszczuk - rédacteur

Katarzyna Kapiec - secrétaire de la rédaction

Henryk Meyza - rédacteur thématique du volume

CONSEIL SCIENTIFIQUE DU JOURNAL

M. Kobusiewicz (IAE PAN, Warszawa)

E. Laskowska-Kusztal (IMOC PAS, Warszawa)

D. Michaelides (University of Cyprus, Nicosia)

J.Ch. Moretti (IRAA-MOM, Université de Lyon 2/CNRS)

D. Raue (Ägyptisches Museum der Universität Leipzig)

P. Reynolds (ICREA, España)

D. Welsby (British Museum, London)

COMITÉ SCIENTIFIQUE DE LECTURE

la liste des membres du comité est accessible en ligne sur

http://www.etudesettravaux.iksiopan.pl

RÉDACTION TECHNIQUE

Marta Kaczanowicz

REVUE DES TEXTES EN ANGLAIS

Jo Harper 
ÉTUDES et TRAVAUX XXXIV 
INSTYTUT KULTUR ŚRÓDZIEMNOMORSKICH I ORIENTALNYCH POLSKIEJ AKADEMII NAUK

\title{
STUDIA i PRACE
}

\section{XXXIV}

\author{
GoIKSiO \\ QSO PAN \\ WARSZAWA \\ 2021
}


INSTITUT DES CULTURES MÉDITERRANÉENNES ET ORIENTALES DE L’ACADÉMIE POLONAISE DES SCIENCES

\section{ÉTUDES et TRAVAUX}

XXXIV

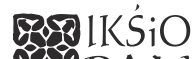

EOSPAN

VARSOVIE

2021 
Publication scientifique financée dans le cadre du programme du Ministre de la Science et de l’Éducation Supérieure

« Programme National de Développement de l’Humanistique » pour les années 2016-2021 (projet no 3bH 150099 83)

\title{
(1) NARODOWY PROGRAM ROZWOJU HUMANISTYKI
}

\author{
Copyright $(C)$ \\ Instytut Kultur Śródziemnomorskich i Orientalnych PAN \\ et les Auteurs \\ Warszawa 2021
}

ISSN 2084-6762

(jusqu'en 2011 : 0079-3566)

e-ISSN 2449-9579
Version première en papier, imprimée en Pologne - 150 copies
Version électronique accessible sur
http://www.etudesettravaux.iksiopan.pl

Édition: Polskie Towarzystwo Historyczne et Wydawnictwo Neriton, Warszawa

Conception générale de la couverture : J. Iwaszczuk

Photographie de couverture : Phot. A. Brzozowska-Jawornicka

(Le portique ionique est, péristyle de la Maison « hellénistique », Nea Paphos) 


\section{Table des matières}

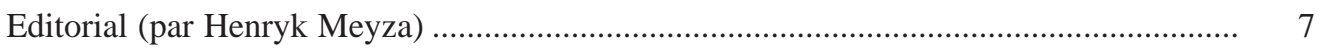

Marta BaJTLER

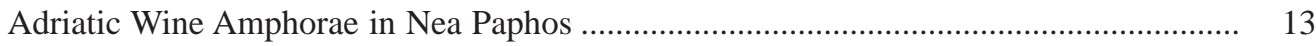

Claire Balandier, Jolanta MlynarczyK

The Temple and Its Surroundings on Fabrika Hill, Paphos: Preliminary Results

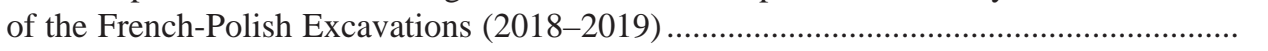

Grażyna BĄKowska-Czerner, Rafal CzERner

The Shell Motif in the Culture and Architecture of the Ancient Town of Marina el-Alamein in Egyp

AleKsandra BrzozowsKa-JaWornicKa

'Hellenistic' House in Nea Paphos, Cyprus - A First Summary of Its Architecture.

AleKsandra BrzozowsKa-JaWORnicKA, AnNa KuBICKA-SowińsKa

In Search of the Module in the Architectural Design of the 'Hellenistic'

House in Nea Paphos, Cyprus

RoKsana HaJduga

Kushite Stamp Impressions from Selib 2, Sudan

ERSIN HusSEIN

Mapping Metal Rich Roman Cyprus: The Case for Object-Centred Approaches

BARBARA LICHOCKA

Villa of Theseus at Nea Paphos (Cyprus). Fourth-Early Fifth Century Numismatic

Evidence for Architectural Transformations and Seismic Events

VASiliki Lysandrou, Demetrios Michaelides

Wall Paintings in Ancient Cyprus: The Hellenistic and Roman Tombs of Paphos

and Its Region

ADAM ŁAJTAR

A Weight of Seleucia in Pieria in Nea Paphos

Diana MroczeK

Ancient Portrait Busts of Marcus Aurelius in the National Museum in Poznań 
Brandon R. Olson, R. Scott Moore, Thomas Landvatter, Justin Stephens

Pyla-Vigla: A Case Study Assessing the Imperial Strategies of the Hellenistic

Diadochoi in Cyprus

Patrizio Pensabene, Eleonora Gasparini

Colonnaded Hall in Kourion: How the Oecus Corinthius Was Interpreted in the Roman

Houses of Cyprus

Monika Rekowska, Demetrios Michaelides, Skevi Christodoulou, JAKUB KANISZEWSKI

Adopting Roman Habits - The Baths in the House of Orpheus in Nea Paphos

as a 'Troublesome' Case Study?

MARCIN M. ROMANIUK

Terracotta Pipelines at Maloutena: Remarks on the Water System in the

Residential District of Ancient Nea Paphos, Cyprus

363

ABRÉVIATIONS

407 